\title{
THE IMPACT OF CROSS-BOUNDARY ELECTORAL DEMARCATION DISPUTES IN SOUTH AFRICA AFTER 1994 The Case Study of Moutse
}

\section{Beauty Vambe and Sipho Mantula}

Beauty Vambe is a researcher in the Department of Mercantile Law, University of South Africa, Pretoria

Sipho Mantula is an advocate and researcher at the Thabo Mbeki African Leadership Institute, University of South Africa, Pretoria

\begin{abstract}
The article investigates the impact of cross-boundary electoral demarcation disputes between the Mpumalanga and Limpopo provinces after 1994. The article further examines how the electoral demarcation disputes can be resolved by negotiating with the dissatisfied communities. Moutse is located within a community that straddles north-western Mpumalanga and southern Limpopo provinces in South Africa. In 2005 the community members of Moutse wards 5 and 6 were dissatisfied by the decision of the South African national government, Limpopo and Mpumalanga provincial governments for relocating them under a newly demarcated administrative boundary without hearing the views of the community. The article used community dialogues for its research. This approach is explained predominantly by qualitative and quantitative approaches to indicate processes of data collection, to explain the nature of the problem and explore the findings of communitybased research. The study reveals that violent disruptions and protests by community members can be avoided if community voices are taken into consideration. The article recommends that state institutions that support constitutional democracy need to show the administrative and political will to transform electoral demarcation challenges and implement effective democratic principles. In conclusion, advanced institutional planning and its transparent application must be emphasised.
\end{abstract}

Keywords: African dispute resolution; cross-boundary disputes; electoral demarcation; community dialogues; constitutional democracy; Moutse community 


\section{INTRODUCTION}

Public participation is paramount in settling disputes between the government and the community. Failure to facilitate community dialogue leads to the suppression of rights, of access to basic amenities, and resultant disputes. Electoral Dispute Resolution (EDR) refers to the remedial methods used to address challenges encountered during the election period. The choice of appropriate EDR method depends on the specific rights abridged. There is an interaction between the electoral process, judicial system and the courts, mediated principally by the right to a fair and impartial hearing (The Carter Center 2009). This interaction can best be understood through the aid of the disgruntled community, the voices of the marginalised, and political will.

The research seeks to investigate the challenges the judiciary faces in the Ephraim Mogale municipality in adjudicating disputes over the border demarcation of land and EDR in the Moutse area. Moutse is located within a community that straddles northwestern Mpumalanga and southern Limpopo provinces in South Africa. The Moutse community members of wards 5 and 6 protested against forced relocation as public participation was excluded. In its response, the judiciary supported public participation in these communities by allowing addresses that existed before 17 December 2003 to be acknowledged and used in the voter's role, the voting process and during community dialogue on cross-boundary demarcation issues. The use of recognisable addresses by the community in the electoral process, was allowed until 30 June 2018. Section 118 of the Constitution binds provincial legislatures to facilitate public participation in the legislative process. The emphasis of community dialogue is on community knowledge of the electoral process, procedure and community input in the decision-making process. The Institute for Dispute Resolution in Africa (IDRA) under the College of Law at the University of South Africa (UNISA) conducted a research study in an attempt to capture and hear the voices of this embattled rural community in South Africa (Nzewi \& Zakwe 2009). The main aim is to allow community voices to speak out on the challenges the community faced during the elections and the best possible solution to these challenges (ibid.). IDRA explored the role of the Constitutional Court, the legislature and traditional courts in involving public participation and democracy in the adjudicating process when electoral disputes occurred. The aim is to show that violence can be prevented and legitimacy enhanced (IDLO 2017).

The main problem this research intends to address can be split into two parts: a) the challenges of adjudicating land demarcation disputes in domestic courts in South Africa, and b) the viability of using community dialogue as an alternative adjudicating process as a remedy for EDR in rural villages of South Africa. The analysis of the viability of establishing the community dialogue method as an 
EDR mechanism will further inquire about the practicability of establishing, or rather, integrating the proposed supranational adjudication mechanism into the existing South African judicial framework. In light of the growing trend of establishing common African democratic standards and seeking a collective solution, this research will attempt to explore the viability of establishing a community dialogue mechanism for resolving disputes on elections and border demarcation in Ephraim Mogale.

\section{HISTORICAL, GEOGRAPHICAL AND DEMOGRAPHIC PERSPECTIVES OF MOUTSE}

Moutse falls under the Sekhukhune District Municipality (SDM) and was established in December 2000. Sekhukhune consists of five local municipalities of which Ephraim Mogale is one. ${ }^{1}$ Modern-day Sekhukhune is located in the Limpopo province in northern South Africa and covers approximately 13264 square metres. Most of this land is rural and lies north west of Mpumalanga and south of the Limpopo. Sekhukhune is located about $200 \mathrm{~km}$ north of Pretoria/ Tshwane, about $150 \mathrm{~km}$ east of Nelspruit and approximately $180 \mathrm{~km}$ north of Polokwane, and is serviced by the Olifants, Tubatse and Elands rivers. The economy of Sekhukhune is driven largely by agriculture, mining and tourism. About $5.3 \%$ of the population is urban and $94.7 \%$ is rural. The map below captures the geographic realities.

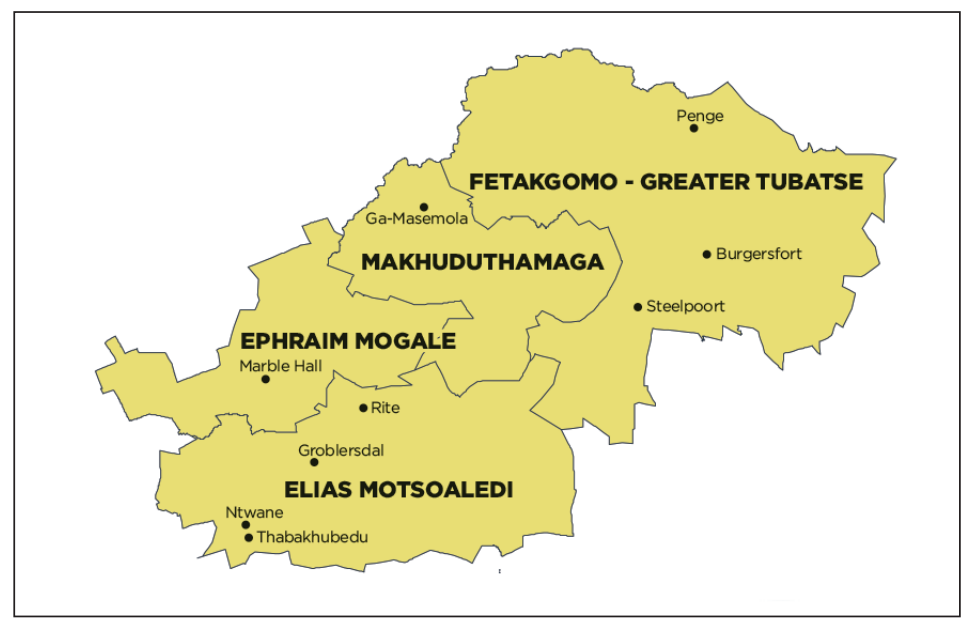

Source: municipalities.co.za

Figure 1 Moutse and its disputed municipalities

1 Sekhukhune municipalities comprise Elias Motswaledi, Ephraim Mogale, Greater Tubatse, Fetagomo and Makhuduthamaga. 
Current census statistics indicate that SDM has 1076840 people in 217000 households (with an average of four people per household) in the municipal areas. Half of the population are below 18 years of age, the male-female ratio is equal and $60 \%$ of the female population over the age of 18 are working. Marble Hall municipality, in which Moutse is situated, had 133115 residents by 2009.

The community of Moutse has occupied the area since 1780 (StatsSA 2011). The occupants are predominantly Sepedi speakers. Their neighbour is an isiNdebele-speaking community occupying the area known as Siyabuswa. In accordance with the apartheid government's legislation (the Promotion of Bantu Self-Government Act 46 of 1959, now repealed) that promoted the policy of separate development, ethnically-based homelands were established for Africans who were classified into eight ethnic groups according to language and culture. In terms of the Bantu Homelands Citizenship Act 26 of 1970 (now repealed) Africans were later assigned citizenship of a homeland established for the ethnic group under which they were classified. Under this scheme, the homeland of Lebowa was established for Sepedi-speaking people, and in 1972 Moutse was incorporated into Lebowa.

It is in view of the foregoing background that this research sought to investigate the challenges facing the judiciary in Ephraim Mogale municipality in adjudicating border demarcation and EDR disputes. In light of the growing trend of establishing common African democratic standards and seeking a collective solution, this research will attempt to explore the viability of establishing a community dialogue mechanism for resolving disputes on elections and border demarcation.

\section{UNDERSTANDING THE PROBLEM OF CROSS-BOUNDARY DISPUTES IN MOUTSE}

Public participation and consultation are paramount in settling disputes between the government and the community. Participation implies that the voices of all parties are given equal hearing, rather than top-down consultations to resolve disputes, which is likely to foment the further breakdown of dialogue. Failure to facilitate community dialogue may lead to a sense of resentment and the suppression of rights, undermining service delivery and prolonging the processes of problem-solving. The net result might not achieve an outcome that satisfies both parties. In this context the emphasis on community knowledge is critical for the conflicting parties to 'own' the processes of interpreting their own problems so as to actively participate as agents implementing plans of action and dispute resolution. 


\section{Emphasis on Community Knowledge and the Voices of Wards 5 and 6 on Elections and Disputes}

The emphasis of the study is on community knowledge and giving a voice to the community members of wards 5 and 6 of Ephraim Mogale on their lived experiences during election disputes. Involving the community in the adjudicating process is a democratic right which promotes peace and stability in the country. The article aims to explore the challenges that rural communities undergo during electoral and land boundary disputes in rural South Africa, and to recommend possible solutions.

This research follows an ethnographic approach whereby the community has to share its lived experiences of cross-boundary electoral demarcation disputes. The research method is based on ethnographic theory which focuses on community dialogue as a method of engaging the community in policy making, how community violence can be prevented and the legitimacy of the electoral process enhanced if the community is part and parcel of the adjudication process (IDLO). The research adopts both qualitative and quantitative approaches to community dialogue as techniques to investigate the causes of violent clashes in crossboundary municipalities and development (Nzewi \& Zakwe 2009). Qualitative methods are used in questionnaires to assess the different responses to a particular question. Community dialogue through radio announcements, drama, role play, public meetings, poetry and dance helps the community to express their thoughts and fears during the electoral process. A case study approach is used to expose in-depth understanding of the cross-boundary electoral demarcation dispute. The frameworks and tools applied are suitable for the analysis and evaluation of the municipal boundary demarcation process. Court cases are also used as primary sources to compare different incidents of community involvement and the courts in EDR and land demarcation disputes. Literature review is used to explore and conceptualise the role of the Constitutional Court, the legislature and traditional courts in public participation, democracy, and the adjudicating process when electoral disputes occurs.

The main findings indicate contrasting views between the community and the municipality, in particular regarding the role of the community in prioritising needs and in decision-making. This results in several municipal demarcations negatively affecting basic developmental services to the community.

\section{Community Dialogue Harnessing the Voice of the Community on Electoral Disputes and Land Demarcation Disputes}

Research ethics and compliance, and reading the informed consent details to participants were conducted by IDRA researchers and community leaders. 
Community leaders officially welcomed village members and IDRA researchers to the gatherings. The main objective of the community dialogue was to try and understand the challenges community members face in local, provincial and national elections. Community members were asked for suggestions on how best to tackle these problems and possible solutions. Of major importance was the community members' proposed solution or preferred method for handling community electoral disputes and crisis. Research objectives were explained and research questions were read and explained in the chosen local language by a member of the community dispute resolution committee (CRC).

Research compliance procedure is crucial as it puts IDRA officials and community members at ease and they feel free to discuss their problems. It also enables community members to focus on research objectives and engage in pre-planned community methods to assess whether the aims were fulfilled.

\section{Theoretical Perspectives on Electoral Boundaries and Demarcation}

Different ways in which electoral boundaries in South Africa are drawn up include the cadastral, topographic and census information (Electoral Commission 2018). Whatever method is followed, the drawing of electoral boundaries and the method of allocating voters should not affect either the electoral process or provision of basic services to the communities. Geographical criteria and administrative, or even historical, boundaries may be included. The Constitution of South Africa, in particular Chapter 7, s155 (3) (b) states, 'National legislation must establish criteria and procedures for the determination of municipal boundaries by an independent authority' (The Constitution of South Africa Act 108 of 1996, supported by the Municipal Demarcation Act of 1998 and the creation of the Municipal Demarcation Board).

The Municipal Demarcation Act also provides the legal basis for the determination of boundaries in South Africa (Constitution of South Africa Act 108 of 1996 Sections 21-24). For the purpose of our investigation, relevant provisions will be quoted extensively to establish the theoretical framework and basis for demarcation.

\section{OVERVIEW OF DISPUTE RESOLUTION IN AFRICA}

The rationale for using customary courts arises out of the realisation that the formal system of justice excluded rural black South African communities from forming and executing legislation (Carpenter 1996, pp. 110-122). The law was largely perceived by black South Africans to be an instrument of oppression. The inability to meet the needs of the ordinary citizens was, however, due not 
only to the content of the substantive law, but also because the structure and procedural requirements of the courts meant that many people were denied access to the courts (Grant \& Schwikkard 1991, pp. 304-316). For many, a dominant, foreign, Western-based legal system was seen as being superimposed on an intuitive, indigenous legal system (Van Niekerk 1994, pp. 19-30). Many of the peculiar problems facing the black community stemmed from the ineffective administration of the justice system in black areas. The legal problems as well as problems of social adjustment encountered by urban black people were not being solved. It was understandable that people resorted to self-help in the form of unofficial or folk institutions. In urban areas, different forms of community courts were instituted.

The new Constitution of South Africa (1996), and its Bill of Rights, is based on the principle that all people are equal before the law. The problem is that the equality thus achieved will be more of a facade than a reality if people are still de facto excluded from representation, due to past injustices. Most black people do not have the economic, social or cultural ability to make use of those rights or to participate meaningfully in the administration of justice in EDRs when official administration manipulates the powers. The most common general complaint about the current justice system in South Africa is the prohibitive cost of litigation, which prevents meaningful access to courts and even those with access are often victims of delay. For most litigants, delay means added expense and for many people justice delayed is justice denied. Delay combined with the cost of litigation has put justice beyond the reach of the ordinary citizen. The incomprehensibility and adversarial nature of the process with a resulting lack of control (parties can only participate in an indirect manner) furthermore leads to a sense of frustration and disempowerment. Courts offering only trials are furthermore limited in their response to a legal dispute. Litigation often creates winners and losers and even winners may feel like losers given the limited nature of many legal remedies imposed from a limited range of win or lose options.

What is necessary therefore is an attempt to add a social dimension to the formal courts in terms of which even the disadvantaged and poor will be entitled to representation and information. In this setting consideration may be given to alternative remedies and processes, which may make justice fair and more accessible. Community courts have an important role to play even in the new dispensation. In short, alternative dispute resolution (ADR) is a conceptual approach that refuses to oppose customary law to formal modern legal system, and instead prefers to harness traditions in the context of a modern regulatory legal framework. Using these systems of resources to law, the research proceeded to sample the views of village elders on electoral disputes. 


\section{Theoretical Foundations for Community-Based Traditional Conflict Resolution}

In traditional Rwanda, the basic and most important unit of socialisation was the extended family. Status within the society was divided along gender and age lines (Ingelaere 2008, p. 33). After the Rwandan genocide of 1994, the Rwandan government institutionalised Gacaca courts as a means to obtain justice and deal with most of the genocide cases that the formal courts and International Criminal Tribunal for Rwanda (ICTR) could not handle. In Botswana, among the Tswana, customary dispute resolution runs parallel to the formal justice system (Myer \& Shihn 2010, p. 6). Dispute resolution by community elders in South Africa has a pluralistic legal system. These traditional methods of dispute resolution are informed by the theories of community participation debated below.

Before colonialism, most, if not all African societies lived communally and were organised along clan, village, tribal and ethnic lines. Being part of a community was important, if not essential due to the vicissitudes of life in primal or communal societies. Social ties, values, norms and beliefs and the threat of excommunication from the community provided elders with legitimacy and sanctions to ensure their decisions were complied with. Consequently, social theories try to explain why the elders were able to resolve disputes in such contexts. The social capital theory explains the formation of communal societies and the attendant social ties, networks, bonds, reciprocal duties and trust that bind people together and enable them to coexist (Putnam 2000; Kenyatta 1965). This theory also explains the restorative nature of dispute resolution by emphasising the social ties or social capital that had been broken by wrongs, committed or omitted. ${ }^{2}$ Putnam emphasises the importance of the social solidarity theory proposed by Durkheim (1933), who explains society in terms of social order and social facts. In this theory, individuals in society are social actors who are restrained by functionalist social facts. These exist only if society can derive utility or benefits from them.

The optimal psychology theory uses culture to explain how people view reality, live and resolve disputes (ibid.) and argues that while dispute resolution in African societies is aimed at repairing social ties and restoring harmony, 'the received' justice systems are mainly retributive with a winner-loser ideology. This theory is important in understanding the resilience of traditional dispute resolution in modernised and westernised African societies.

2 In an interview with the author, the Kipsigis Council of elders emphasized how it was difficult, for example, for a couple to undergo divorce in the community. They said that the elders had to give the couple time to ensure that they amend the situation and encouraged them not to divorce. 


\section{Opinions and Experiences on Cross-Boundary Electoral Demarcation Disputes}

The village elders at Moutse put forward their own views regarding electoral disputes and challenges in their communities in South Africa. The community felt that traditional authorities should be involved in findings ways to resolve electoral disputes. Involving the consent of the community empowers it to feel that it owns the process of demarcating boundaries. If the community is not involved there is confusion about who is in charge or responsible for the demarcation processes and this creates further tension within the affected communities. The traditional way of resolving electoral disputes accommodates the indigenous people, encourages cooperation and gives everyone a chance to participate in the election process. Community elders feel that the traditional method is fairer to the older generation and to those who do not have formal education. The use of traditional methods and the participation of elders brings peace and harmony to the embattled and disjoined fabric of the community. The community also responded to the methods used in researching the problem of straddled communities. After offering their appreciation of the significance of community engagement, elders also aired their perceptions of the role of the IEC and EDR.

The community of Ephraim Mogale complained that during elections there were no given dates or places to meet and discuss issues that concerned the community. The community lamented the fact that promises are not carried out or fulfilled in terms of arranging meetings for their own good. There is no independent public platform to air their grievances due to this lack of commitment and follow-up. Electoral issues are a concern. The community needs outside independent and impartial assistance to help adjudicate electoral issues. Universal freedom of adult suffrage is denied the elderly as they told who to vote for and are threatened with losing their pension funds if they choose the wrong candidate. Intimidation is rampant as electoral rules are flawed when various political parties wear T-shirts indicating their party allegiance at the polling stations during voting time. Votes were rigged as voters were psychologically and physically threatened if they did not vote for a certain candidate. There was no transparency in these voting stations.

Although there are threats during both local and national elections, the traditional council is supposed to lead dispute resolution in such chaotic situations. Whenever there are challenges, the people can consult with their traditional authority. Some community members pointed out that the traditional council frequently creates chaos in the community because council members seem to absolve themselves from matters which are of great importance to the community. Because of corruption, traditional authority is no longer trusted; 
even when a gathering is called, there is no commitment, as members do not turn up. People have lost hope and trust in traditional authority. There is a feeling that traditional council leaders are used as pawns and have been replaced by self-appointed leaders, and this is of great concern. The community feels that it should be sufficiently empowered to help the village, so the IEC should clarify its responsibilities. Anyone who tries to support the embattled community is afraid of being killed. Some community members feel that where the traditional council fails, the police and courts should step in as the IEC and the police can provide security in electoral disputes. However, there is no unity and no one wants to endanger their lives.

Within the community, there were also different voices putting forward sometimes contradictory statements. One member wanted to see people unified around the traditional system of dispute resolution, asking why the community used this foreign system when the community had its own methods of resolving disputes. In this member's own words: 'The foreign system does bring a lot of challenges as it keeps the community in the dark. We are scattered around as community members because of demarcation. Therefore, we are not able to meet whenever there are issues which must be resolved'. Furthermore, the member summed up his view by saying 'Divided you cannot stand but together you can, and that's my opinion' (IDRA 2014), emphasising the importance of traditional African dispute resolution.

Another member saw the role of the IEC differently, remarking:

As farm and plot owners, it would be best to meet and appoint our own representatives as in this manner, we can achieve a common purpose. Plot owners are different from other common villagers. As a result our needs should be attended as a means of urgency and patience. We do not have chiefs here or headman, as a result we see no need to subject ourselves to traditional rulings as we do not abide or live under such contexts. From what I gather, we are a special community and our needs are different from others, why are we associated with these that are different from us?

There is a considerable distance from one plot to the next, so transport is a very valuable commodity. Even when a loud speaker is mounted on a motor vehicle advertising the meeting, the driver and announcer have a long way to go. Lots of petrol and energy are needed, more so for those who walk to the meetings. Matatadibeng, Mokwaneng and Mamaneng should have their own councillor. This statement shows the importance of owning private property. The MBD should consider the challenges faced by plot owners as different from those of 
high-density rural areas. The people want to select someone from their own community as a separate councillor chosen by that community and who lives in the same community. Radio announcements, posters and flyers are very effective methods of publicising the meetings.

A plot owner continues:

A councillor cannot stay far away from his or her ward. We prefer if we had one of our own members selected as councillor in Mamaneng and not Ga Matlala'a Ramoshebo village. Sometimes we lack information and the resources to tackle certain issues. It is that we need the MEC or the Sekhukhune district to intervene. I think this formal system can work for us. We have registered for the RDP houses at the same time as other villages but the other villages have surpassed us. I think Limpopo Province is too slow in responding to peoples' needs. It is better if we are returned to Mpumalanga. We are having an unknown counsellor who stays far away from us. He cannot help us when we have a crisis, we do have ward committees but they do not have the proper knowledge on how to assist us because they hardly receive any briefing from the counsellor.

Some community members have strong views on home-based care:

We now have home-based care in this village but this is the third year and we are not getting any cent from the government. We cannot see the councillor to discuss the matter. We cannot receive proper services because our councillor resides in another area. I doubt if we are accommodated in these national budgets. We do not know where Ward 5 begins. It would be a good idea to give a seven-day notice prior to a community meeting. The lack of service delivery is indeed a challenge. I think we do not have access to valuable information, especially in terms of development within our community. We need a proper protocol through which our complaints are or will be addressed. We should also implement structures that accommodate the elderly, the sick and disabled people of our community. They too deserve to know what is happening in their community.

The above comment highlights the need for accessible primary health care facilities.

We do not really meet as we live in plots. It is difficult to know what is happening in the next plot. We are in the dark. To be frank with you, 
we do meet as different members, who belong to different political parties, but this only happens amongst members of the same political party. As a community, we do not really meet, except in voting stations.

The above comment shows the importance of community dialogue in that it cuts across tribal and political lines. Disputes and challenges faced by members require community members to provide solutions from within and not from outside the residential area.

Members expressed their expectations of what the IEC should do for them. One member commented:

People who reside in plots feel that they need to be given voter education as some of the community members do not know their rights when it comes to votes. When voting comes, we should gather as a community and see to it that we try to have a fair election process. The IEC should get involved in such a process whereby we would be given community workshops and trained to be observers during that time. We should move away from tea-party politics and address issues that affect the whole community.

Voter education is necessary for all community members in a language they understand, and voters should be educated about their rights and duties as South African citizens. Another member appreciated the importance of research into the problem of Ephraim Mogale's straddled borders:

Your research questions are thought-provoking and this makes me happy and I hope I can speak for the community members as well. We are pleased to know that we have the knowledge and that it can be valuable during the election dispute. To see that an academic institution does take the initiative and engage with the people is a very important lesson to all of us and we appreciate such efforts. Municipalities must get involved in election disputes. I support the previous speaker. I agree with her views. Sometimes we vote and we don't know who won. The government departments which are responsible for various issues should be consulted as well such as the demarcation board. The elderly people should now rest and it is now up to the youths to bring about meaningful positive change. We should share ideas and help each other grow.

The above comment indicates that the community members are aware of the importance of research and feedback. Neutral research enables different 
community members to communicate freely with each other about their challenges and suggestions for possible solutions with fear, intimidation or discrimination. Judging by the views of community members, there is a sense in which they feel that they should be involved in tackling the problem in Mogale for the community to feel that they own the process of resolving their problems. One member commented as follows:

This is our project and we feel proud to participate in it together as one. The presence of researchers in these villages will enlighten us even further. The traditional authority mainly concerns itself with native issues because issues such as conflict can be complicated for them to resolve. It is then that the police and the courts can step in to resolve such matters. The appointment of counselors should be based on proper leadership and not based on unknown interests. A Community Research Committee will have to be the voice of this community. They should report to us and serve as our voice in these matters. If a child has erred, it is the parent's responsibility to teach and build the child ... the same policy should be adhered to in our disputes as well. We are one people.

It is important to establish recognised structures to help members in resolving disputes, and that the community take ownership of the project and process of resolution.

\section{THE ROLE OF GOVERNMENT INSTITUTIONS AND AGENCIES IN ELECTORAL DEMARCATION DISPUTES}

The Electoral Commission of South Africa (IEC) and the Municipal Demarcation Board (MBD) need to educate people about the election and demarcation procedure and ensure that everyone votes freely and participates in redrawing the boundaries. The IEC is the custodian of voting rules and regulation. It has an electoral court to solve disputes after the election process, can make use of the traditional courts to adjudicate electoral disputes, and challenges the use of conventional (legal) or traditional courts. The IEC conducts pre-election voter education, publicises the elections, organises voting during the election and continues to participate after the election until all matters are resolved. Objectives of the demarcation board are established in the 1996 Constitution and include determining municipal boundaries, upholding Chapter 7 constitutional legislation and publishing the boundary demarcation in the provincial gazette (see appendix). 


\section{Constitutional Cases involving Electoral Demarcation Disputes in South Africa}

Some municipalities have been demarcated in such a way as to straddle provincial boundaries. The Twelfth Amendment removed cross-border municipalities but community dialogue was needed in the procedure. The community voice was the deciding factor, as change in administration would affect social, political and economic life. Adjacent provinces were then forced into a geo-political arrangement to settle local government projects. This has led to time-consuming and labour-intensive bureaucratic consultations between local and district municipalities as well as provincial departments. Examples of this kind of demarcation problem are found in Merafong, Matatiele and Moutse. The Tlokwe case concerns the failure to provide correct voter addresses and lack of public participation in the recording of these address.

\section{THE MOUTSE DEMARCATION FORUM CASE}

The residential community of Moutse was moved from Mpumalanga province to Limpopo under the Twelfth Amendment of the Constitution. The Moutse community believed they had been transferred to a dysfunctional province and took their grievance to the Constitutional Court to try and reverse the matter (Moutse Demarcation Forum and Others v President of the Republic of South Africa and Others (CCT 40/08) (2011)ZACC 27;2011(11) BCLR 1158 (CC). The Court ruled against the community and argued that proper procedures were followed on the amendment and the case was dismissed. The community, however, was not involved in the decision making-process. They felt abandoned and sought redress of the situation.

Before these laws were passed, the areas of Moutse 1 and Moutse 3 fell under the province of Mpumalanga, as part of separate local municipalities located within the Greater Sekhukhune District Municipality. Sekhukhune Municipality is seen as a straddled or cross-border municipality located between the provincial boundaries of Limpopo and Mpumalanga. The purpose of the challenged laws was to abolish these cross-boundary municipalities by altering provincial boundaries.

The challenge was brought by a community organisation and opposed by the national government, the provincial legislatures and governments of the provinces of Mpumalanga and Limpopo respectively. The Moutse Demarcation Forum challenged the validity of the Twelfth Amendment, whether or not the procedure set out in section 74(8) of the Constitution had been complied with and whether or not section 118 (1) (a) of the Constitution was engaged. First, the applicants argued that the laws were irrational because they perpetuated boundaries drawn by the apartheid-era government in pursuit of its policy of separate development. Second, 
they contended that the Mpumalanga Provincial Legislature was required to and had failed to consult reasonably with the residents of Moutse 1 and 3, the people most pertinently affected by the changes. This, they said, was because they were given too little notice of the hearing, the hearing itself was too brief and because the report of the Portfolio Committee to Parliament did not sufficiently reflect the objections of the community.

Reasonable consultation may not take whatever form chosen by a legislature but it should involve the norms and values of the community affected. It is the rural people (i.e. those most affected by this legislation) who should choose the form of consultation, not the legislature. The enforcement seems to be contiguous with that of the apartheid era. In this case the provincial legislature opted for public hearings. A hearing was held in Moutse 1 but not in Moutse 3 until the community held a protest march to the Union Buildings in Pretoria on 6 December 2005. Following the march, a hearing was held in Moutse 3 on 8 December 2005 at which the community, through its representatives, voiced its opposition to the transfer of the area to Limpopo. The Portfolio Committee recorded this but recommended to the provincial legislature that the laws be supported. The recommendation was endorsed by the provincial legislature.

\section{THE KHUTSONG DEMARCATION CASE}

A small portion of the southern area of the Merafong Municipality fell into the North West Province under Khutsong, with the rest of Merafong in Gauteng. Faced with the challenges of poor service delivery in cross-border municipalities, the people of Khutsong took their grievances to court in 2005. The Merafong community challenged the validity of the Twelfth Amendment in Merafong Demarcation Forum and Others vs President of the Republic of South Africa and Others (CCT 41/07 [2008] (10) BCLR (CC). The Khutsong community's argument was that the Gauteng provincial legislature failed to comply with section 118 of the Constitution of 1996 in its obligation to facilitate public involvement in the processes of approving the Twelfth Amendment Bill. The standoff between Gauteng and the community of Merafong highlighted complex constitutional arguments, which prompted constant action from the courts. When their request was refused, the Khutsong community engaged in violent protests.

Borders should probably be redrawn only after consultation with affected communities. Laws should be drafted with the people in mind and not forced upon them. Protests occur when grievances of the masses are not addressed amicably. A swifter method of solving disputes should be followed and legal education is necessary for the ordinary people, and while it is necessary to prevent violence, the law should protect the people and not punish them. 


\section{MATATIELE}

The issues before the court included the validity of the Twelfth Amendment, whether the procedure set out in section 74(8) of the Constitution had been complied with and whether section 118(1) (a) of the Constitution was enforced in the decision-making process and lack of community engagement in the procedure.

In 2006 the Matatiele Municipality challenged the constitutional validity of the Twelfth Amendment and the Cross-Boundary Municipalities Laws Repeal and Related Matters Act ( Matatiele Municipality and Others $v$ President of the Republic of South Africa and Others. CCT 73/05. Decided on 27 February 2006). They argued that proper procedures for transfer were not followed. The Matatiele Local Municipality was transferred from KwaZulu-Natal to the Eastern Cape due to the creation of new municipal boundaries. The applicants argued that these laws changed the boundary of Matatiele Municipality and its composition and transferred it to the Eastern Cape without complying with the procedure set out in the Constitution. Parliament took over the functions which the Constitution had reserved for an independent authority, the Municipal Demarcation Board. The respondents argued that in passing the Twelfth Amendment, Parliament had complied with the procedures set out in the Constitution. In addition, they argued that Parliament was entitled, in the exercise of its powers, to alter provincial boundaries, and to interfere with municipal boundaries if this was necessary to re-draw provincial boundaries.

The Court gave its judgment on whether the procedures set out for passing the Twelfth Amendment were complied with by the KwaZulu-Natal Legislature. The Court found that the Municipal Demarcation Board is an independent authority which is vested with the power to draw municipal boundaries. By entrusting this power to an independent authority, the Constitution seeks to guard against political interference in the process of creating municipal boundaries. For this reason, the Board should be able to determine municipal boundaries without being constrained in any way by the national and provincial governments. However, the power of the Board to determine municipal boundaries is limited by the authority of Parliament to re-draw provincial boundaries. The Court concluded that the Twelfth Amendment did not violate the Constitution in interfering with municipal boundaries in the course of redrawing the provincial boundaries.

The idea that the Twelfth Amendment is not invalid on the grounds relied upon by the community is worrisome. It suggests that there are grounds but the community should raise them and not the judges. The idea is that it is not in the interests of justice to postpone the case for the purpose of investigating whether the procedure set out in section 74(8) of the Constitution has been complied with and whether section 118(1) of the Constitution is engaged. There seems to be no 
separation of powers between the judiciary and parliament. The laws and the community appear disconnected with no prospects of a convergence. The court holds that the likelihood of the applicants benefiting from this course is far too small to justify further investigation and consequent delay. The people protest as they feel rejected and used by the government they had elected to power. Legal technicalities and unfathomable legalese choke the trust between the people and the courts.

It is important to resolve the issue of redrawn provincial boundaries and not leave it undetermined. The conduct shown by the government concerning the objective served by relocating Matatiele to the Eastern Cape, indicates that the legitimacy of legislation comes not from awe but from openness.

\section{TLOKWE CASE}

In 2016 a group of independent candidates in Tlokwe brought a case against the IEC regarding the common local voters' roll and other allegations of electoral misconduct. ${ }^{3}$ This was a constitutional law case between the IEC and independent candidates. Several independent candidates had lost the 2016 by-election held in the Tlokwe Local Municipality and challenged the freeness and fairness of the elections due to a flawed and defective voters' roll. These candidates argued that voters' addresses were not recorded and most voters were registered in the wrong districts. The question was the date from when addresses are to be recorded before the elections? And if the IEC is unable to correct the voters' roll before the elections are held, should the elections be postponed or proceeded with even if the voters' roll is defective?

The IEC went to the Constitutional Court to have the Electoral Court's decision set aside because addresses used by the voters were invalid as the IEC was not obliged to record invalid addresses on the voter's roll. The IEC wanted the elections to proceed regardless. In the event that the appeal should fail, the IEC sought direct access to the Constitutional Court asking that it be absolved from the obligation to provide voters' addresses.

The IEC's appeal was rejected because they had failed to record recognised or available addresses on the voter's roll from 17 December 2003, as required according to section 16(3) of the Electoral Act. Recognised addresses could be used in the upcoming elections until 30 June 2018. Tlokwe was therefore to be excluded from taking part in the August 2016 elections. Direct access to the Constitutional Court was granted.

3 The issue was heard at the Constitutional Court Of South Africa between the Electoral Commission of South Africa and Aaron Pasela Mhlope and Others . CCT 55/16 Date of hearing: 9 May 2016 Date of judgment: 14 June 2016. 
The first judgment differed from the majority judgment in only two respects: firstly, that section 16(3) of the Electoral Act obliges the IEC to record all addresses that are objectively available, even for voters who registered before 17 December 2003. Use of addresses which predated 17 December 2003 shows a commitment by the judiciary to involve community members in the legislative decisions that affect the day-to-day running of local municipalities. Secondly, the IEC's failure to record the addresses on the voters' roll, where available, was in breach of section 190 of the Constitution and resulted in the exclusion of the public from the electoral process. Suspension of section 190 by the judiciary empowered the community by allowing the same addresses to be used in upcoming elections until June 2018.

\section{CONCLUSION AND RECOMMENDATIONS}

The aim of the article was to investigate the nature of border disputes in Moutse community with the intention of hearing the voices of the people. The article used both qualitative and quantitative approaches to indicate data collection processes in order to explain the nature of the problem and capture the research findings. The study revealed that violent disruptions and protests by community members could have been avoided had community voices been taken into consideration in deciding the best possible solutions on adjudication methods. The research discovered that ADR methods were favoured by the community, using the knowledge of the elders in the community. The article debated the concepts of EDR and focused on the appropriate remedy for the abridged right. The article argued that the ADR embraces the pluralistic nature of African legal systems and recommends harmony between the courts and the community demanding remedy. It was observed that the community members of Moutse had different views on electoral demarcation issues. Most people preferred the customary system as it involved traditional culture and norms of dispute resolution. Traditional leaders played an important role in resolving disputes and maintaining the cultural stability between young and old. However, other members, particularly those with plots, believed that the IEC had an important role to play.

In light of the points raised in the conclusion, this article recommended that:

- Traditional authority be involved in dispute resolution;

- The IEC should continue seeking lasting solutions to the problem of straddled communities;

- Research into straddled communities needs to capture the voice of those communities;

- The government needs the political will to implement what is agreed upon in customary and modern courts; and 
- Institutes of dispute resolution need to put pressure on the South African government to be proactive and not wait for other problems in the straddled community to become violent before acting.

\section{----- REFERENCES}

Bantu Homelands Citizenship Act 26 of 1970 (South Africa).

Carpenter, G A 1996, 'Public opinion, the judiciary and legitimacy', South African Public Law, vol 11, issue 1, pp. 110-122. https://journals.co.za/content/ sapr/11/1AJA

Durkheim, E 1933, The Division of Labour in Society, Macmillan, New York.

Electoral Commission of South Africa and Aaron Pasela Mhlope and Others. CCT 55/16

Electoral Commission of South Africa 2018, About voting districts and stations IEC, www.elections.org.za (Accessed 18 May 2018).

Grant, B \& Schwikkard, PJ 1991, 'Peoples Courts', South African Journal of Human Rights, vol. 7, pp. 304-316.

Ingelaere, B 2008, ‘The Gacaca Courts in Rwanda'. In L Huyse \& M Dalter (eds.), Traditional Justice and Conflict Resolution After Violent Conflict: Learning From African Experiences, IDEA, Stockholm.

Institute for Dispute Resolution (IDRA) 2014, Personal interview, Moutse, October to December.

Interim Constitution of the Republic of South Africa 1993 (sections 124(2) and (3)(a)).

International Development Law Organisation (IDLO) 2017, Avoiding violence and enhancing legitimacy: judicial preparedness for handling electoral disputes in Kenya and beyond. www.idlo.int (Accessed 30 June).

Kenyatta, J 1965, Facing Mount Kenya: The Tribal life of the Gikuyu, Vintage Books, New York.

Local government: Municipal Demarcation Act 27 of 1998, as amended by local government laws amendment Act 19 of 2008 (South Africa).

Matatiele Municipality and Others $v$ President of the Republic of South Africa and Others, CCT 73/05. Decided on 27 February 2006

Merafong Demarcation Forum and Others v President of the Republic of South Africa and Others (CCT 41/07) [2008] ZACC 10; 2008 (5) SA 171 (CC); 2008 (10) BCLR 968 (CC) (Accessed13 June 2008)

Moutse Demarcation Forum and Others v President of the Republic of South Africa and Others (CCT 40/08) (2011)ZACC 27;2011(11) BCLR 1158 (CC) (23 August 2011)

Myer, LJ \& Shihn, DH 2010, 'Appreciating Traditional Forms of Healing Conflict and in Africa and the World', Black Diaspora Review, vol. 2, no. 1. http:// www.academia.edu/3157464/PEACE TRADITIONS AND CONFLICT RESOLUTION TRADITIONALAPPROACH. Accessed 30 July 2017. 
Nwezi, O \& Zakwe, L 2009, Democratising regional integration in South Africa: SADC National Committees (SNC) as platforms for participatory policy making, Centre for Policy Studies, Johannesburg.

Promotion of Bantu Self-Government Act 46 of 1959 (South Africa).

Putnam, RD 1995, 'Bowling Alone: America's declining social capital', Journal of Democracy, pp. 65-68. https://archive.realtor.org/sites/defaulkt/files/ BowlingAlone.pdf

South Africa 1995, [interim] Constitution of the Republic of South Africa, Second Amendment Act 44 of 1995 (sections 13 and 118).

The Carter Center 2009, International Obligations for Electoral Dispute Resolution Discussion Paper, February 24-25, Atlanta, GA.

Van Niekerk, GJ 1994, 'People's courts and people's justice in South Africa: new developments in community dispute resolution', De Jure, Vol. 27, no 1. 


\section{APPENDIX}

Determination of municipal boundaries ss 21and 22.

\section{Determination of boundaries}

(1) The Board-

(a) must determine municipal boundaries in the territory of the republic; and

(b) may redetermine any municipal boundaries determined by it in terms of paragraph (a).

(2) Any determination or redetermination of a municipal boundary must be consistent with this Act and other appropriate legislation enacted in terms of chapter 7 of the Constitution: Provided that section 26 does not apply where the board redetermines a municipal boundary in respect of which the MEC of local government and all the municipalities that are affected by the redetermination have indicated in writing that they have no objection to such redetermination.

(3) The board must publish its determination or redetermination of a municipal boundary in the relevant Provincial Gazette.

(4) Any person aggrieved by a determination or redetermination of a municipal boundary may within 30 days of publication of that determination submit objections to the Board.

(5) The Board must-

(a) consider any objections;

(b) either confirm, vary or withdraw its determination; and

(c) publishing its decision in terms of paragraph (b) in the relevant Provincial Gazette.

(6) Any person may, subject to the Promotion of Access to Information Act, 2000. (Act 2 of 2000), request the Board to provide reasons for its decision in terms of subsection (5) (b).

\section{Work programme}

(1) The Board performs the functions mentioned in section 21(1)-

(a) on its own initiative;

(b) on request by the Minister or a MEC for local government; or

(c) on request by a municipality with the concurrence of any other municipality affected by the proposed determination or redetermination.

(2) The Minister may, after consultation with the MEC's for a local government and the Board, determine priorities and reasonable time-frames for a determination or redetermination. 
(3) Where the Board performs the function mentioned in section 21(1) on its own initiative as a result of receiving a request from a member of the public, the Board may-

(a) require that member of the public to furnish the Board with such information as may be required by the Board; and

(b) solicit the views of the persons and institutions referred to in section 26 (3) on the matter before the Board.

(4) Where the Board has solicited the views of persons and institutions as provided for in subsection (3) (b), the Board does not need to comply with s26 when it considers, the determination and redetermination of municipal boundary under the circumstances referred to in subsection (3).

(5) Where the Board performs functions the function mentioned in section 21(1) request by a municipality, the Board may require that municipality to furnish Board with such information as may be required by the Board. 